Puheenvuoro

\title{
Vaikuttavien lasten ja nuorten psykososiaalisten menetelmien käyttöönoton tukeminen päätöksenteossa 2020-luvun Suomessa
}

\author{
PETRA KOUVONEN \& MARJO KURKI
}

Lasten, nuorten ja perheiden palveluja kehitetään osana Tulevaisuuden sosiaali- ja terveyskeskusohjelmaa (Tulevaisuuden Sote -ohjelma), jonka yhtenä keskeisenä tavoitteena on toiminnan painotuksen siirtäminen raskaista palveluista ehkäisevään ja ennakoivaan työhön. (STM 2020.) Resurssien siirtäminen korjaavista palveluista ennaltaehkäiseviin ja mahdollisimman varhaisen vaiheen hoitoon on mielekästä sekä inhimillisestä että taloudellisesta näkökulmasta. Käytännössä se tarkoittaa painopistettä peruspalveluihin, joissa perheet saavat vaikuttavia interventioita matalan kynnyksen periaatteella ja, jolloin erityistason hoitoon, kuten erikoissairaanhoito ja lastensuojelu, ohjautuisi vain ne, jotka sitä eniten tarvitsevat.

Tutkimusperustaisessa päätöksenteossa toimia tulisi kohdentaa väestöryhmiin, jotka nykyisellään maksavat yhteiskunnalle paljon, mutta joiden auttamisella on saavutettavissa suuria hyötyjä (ns. high cost-high impact väestöryhmät). Tuoreen mielenterveysstrategian tavoitteeksi onkin asetettu, että vuonna 2022 perustason palveluissa tulisi olla käytössä vaikuttavaksi todetut menetelmät eri ikäryhmien yleisimpien mielenterveyshäiriöiden varhaiseen hoitoon (Vorma ym. 2020). Tutkimusnäytön mukaan erityisesti lapsille ja nuorille suunnatut vaikuttavat interventiot ovat kustannusvaikuttavia, koska niiden hyödyt voidaan mitata aikuisuudessa lähes joka elämänalueelta, kuten fyysinen ja psyykkinen terveys, koulutustaso, työkyky. Kustannusvaikuttavuuden näkökulmasta esimerkiksi lapsuusiässä alkavien käytösongelmien tunnistaminen ja hoito on tärkeää, sillä niiden jatkuminen negatiivi- sena kierteenä aiheuttaa kaikkein suurimmat syrjäytymisestä aiheutuvat kustannukset. (Knapp ym. 2011.)

Tässä puheenvuorossa esittelemme kaksi näkökulmaa, joilla vauhditetaan näyttöön perustuvien menetelmien kiinnittymistä osaksi peruspalveluita ja siihen liittyvää päätöksentekoa siten, että ne tukevat sekä mielenterveysstrategissa että Tulevaisuuden Sote -ohjelmassa asetettuja tavoitteita.

Ensimmäinen näkökulmamme on Voimaperheet-toimintamalli, joka toimii puheenvuorossamme esimerkkinä siitä, miten menetelmän ominaisuudet (mm. digitaalisuus), sen juurruttamiseen tarjottu tuki ( $\mathrm{mm}$. fideliteetin, eli menetelmäuskollisuuden varmistaminen) ja kiinnittäminen palvelujärjestelmään (tässä neuvolaan) vauhdittaa tätä kehitystä. Voimaperheet-toimintamallin kohderyhmä toimii myös esimerkkinä epidemiologisesti perustellusta väestöryhmästä, joihin kohdennetuilla toimilla on saavutettavissa suuria hyötyjä, koska riskiryhmille kohdennetut varhaisen vaiheen hoito-ohjelmat, kuten lasten käytösongelmiin suunnattu Voimaperheet-hoito-ohjelma, vähentävät kansanterveydellisesti merkittäviä mielenterveysongelmia väestössä.

Toisen näkökulmamme lähtökohtana on käytetty ns. "rapid learning -kehystä". Rapid learning viittaa järjestelmään, joka 1) tunnistaa tehokkaasti, ja 2) tarjoaa vaikuttavia toimia havaittuihin aukkokohtiin hyvinvointitietoa hyödyntämällä (Etheredge, 2014).

Se, miten näyttöön perustuva tieto "rapid learning -kehyksen" mukaisesti siirtyy (tai ei 
siirry) käytäntöihin suomalaisessa järjestelmässä, kiinnitetään tässä Abraham Wandersmanin ym. kehikkoon (the interactive systems framework for dissemination and implementation) (2008) sekä John Lavis ja Heather Bullockin (2019) tuoreeseen vertailevaan analyysiin välittävien organisaatioiden paikasta kolmessa hyvinvointijärjestelmässä. Lavisin ja Bullockin analyysissä kolmen eri mielenterveyspalvelujärjestelmän implementointivalmiuksia (Kanada/Ontario, Uusi Seelanti, Skotlanti) verrattiin implementointia tukevien rakenteiden näkökulmasta. Keskeisenä tuloksena oli, että implementoinnin kannalta järjestelmässä tietoa välittävien toimijoiden (ns. intermediaries) roolit ovat tärkeä selkiyttää sekä varmistaa niiden toimijoiden kapasiteetti, joilla on keskeinen rooli tiedon siirtämisessä.

\section{VOIMAPERHEET-TOIMINTAMALLI ESIMERKKINÄ, JOKA YHDISTÄÄ VAIKUTTAVAN MENETELMÄN VAHVAT IMPLE- MENTOINTIOMINAISUUDET SUOMALAISEN HYVINVOIN- TIYHTEISKUNNAN TOIMIVIIN RAKENTEISIIN}

Suomalainen Voimaperheet-toimintamalli on kehitetty lastenneuvolaan alle kouluikäisten lasten käytösongelmien tunnistamiseen ja varhaiseen hoitoon. Voimaperheet-menetelmällä on vahva vaikuttavuusnäyttö, ja se perustuu vanhempainohjaukseen, joka on vaikuttavuudeltaan tehokkain hoitomuoto lasten käytösongelmissa. Turun yliopiston lastenpsykiatrian tutkimuskeskuksen työryhmän kymmenen vuotta kestänyt mittava Voimaperheet-toimintamallin kehittämis- ja tutkimustyö perustuu digitaalisen etähoidon hyödyntämiseen. Voimaperheet hoito-ohjelma toteutetaan digitaalisessa hoitoympäristössä, jolla on monia etuja kasvokkain tapahtuvaan hoitoon nähden. Palvelujärjestelmän näkökulmasta digitaalisesti toteutettu hoito lisää merkittävästi alueellista tasa-arvoisuutta hoidon saatavuudessa. Perheiden näkökulmasta digitaalinen hoitoympäristö on käytettävissä ajasta ja paikasta riippumatta. Hoito toteutetaan perheen yksilölliset tarpeet huomioiden internetissä perhevalmentajan viikoittaisten puhelujen tukemana. Henkilökohtainen puhelinvalmennus ammattitaitoisen perhevalmentajan kanssa mahdollistaa tavoitteellisen työskentelyn perheen kokemien ongelmien ratkaisemiseksi ja asetettujen tavoitteiden saavuttamiseksi. (Sourander ym. 2016, Ristkari ym. 2019.)

Voimaperheet hoito-ohjelman vaikuttavuutta on tutkittu väestöseulontaan perustuvalla satun- naistetulla kontrolloidulla tutkimuksella (RCT). Tutkimus osoitti, että 11-viikkoiseen ohjelmaan osallistuneissa perheissä nelivuotiaiden lasten käytösongelmat vähenivät olennaisesti verrattuna vertailuryhmään vuoden (Sourander ym. 2016) ja kahden vuoden seuranta-aikana (Sourander ym. 2018). Kahden vuoden seurannassa todettiin, että mielenterveyspalvelujen käyttö oli hoitoa saaneessa ryhmässä selkeästi vähäisempää kuin vertailuryhmissä (Sourander ym. 2018).

Tutkimuksesta saadun vaikuttavuusnäytön jälkeen siirryttiin perusterveydenhuollossa toteutettavaan implementointitutkimusvaiheeseen. Toimintamallia on implementoitu menestyksekkäästi vuodesta 2015 alkaen eri puolilla Suomea, ja toimintamalli tavoittaa kolmasosan kohdeväestöstä. Riskiryhmien tunnistamiseen kehitettyyn Voimaperheet-väestöseulontaan (ns. neuvolakysely) on osallistunut implementointivaiheessa v. 2015-2020 noin 50000 perhettä ja Voimaperheet hoito-ohjelman on suorittanut kaikkiaan noin 2000 perhettä.

Implementointitutkimustulosten mukaan vanhemmat olivat erittäin tyytyväisiä digiavusteisesti toteutettuun vanhempainohjaukseen, kun palvelu tarjottiin kotiin perheen aikataulut huomioiden. Samalla palvelun yhdenvertaisempi saatavuus parani huomattavasti, kun hoito-ohjelma voitiin toteuttaa alueellisesti tasa-arvoisesti. (Ristkari ym. 2019.) Digiavusteinen vanhempainohjaus on mahdollista toteuttaa silloin, kun kasvokkain tapahtuva hoito on vaikea tai mahdoton toteuttaa, kuten kevättalvella 2020 COVID-19 epidemian aikana, jolloin muiden vastaavien psykososiaalisten palveluiden tarjoaminen oli keskeytetty.

Voimaperheet toimintamallin kotipesä on Turun yliopiston lastenpsykiatrian tutkimuskeskuksessa. Jokainen mukana oleva kunta, kuntayhtymä tai SOTE-alue on tehnyt tutkimussopimuksen Turun yliopiston kanssa, joka vastaa implementointitutkimuksesta tuottaen keskitetysti Voimaperheet hoito-ohjelmaa sekä järjestäen riskiryhmien väestöseulonnan. Seuraavassa esitellään implementaatiosuunnitelman keskeiset komponentit, jotka liittyvät sekä kotipesätoimintaan että onnistuneeseen implementaatioon:

Rekrytointi ja menetelmäkoulutus. Kaikki puhelinvalmennusta tekevät työntekijät (jatkossa perhevalmentajat) ovat sosiaali- ja terveydenhuollon ammattilaisia, jotka on menetelmä- 
koulutettu Voimaperheet hoito-ohjelman toteuttamiseen. Viikon kestävä koulutus sisältää teoriakoulutuksen ennaltaehkäisevästä mielenterveystyöstä, käytösongelmista ja vanhempainohjauksesta sekä siihen liittyvään tutkimusnäytöstä, ja käytännön harjoittelun.

Kuntien ja SOTE-alueiden koulutus ja yhteistyö. Uuden alueen perhepalveluiden johtajien ja lähiesimiesten kanssa järjestetään yhteinen puolen päivän koulutustilaisuus, johon kutsutaan mukaan kaikki lasten psykososiaalisissa palveluissa työskentelevät työntekijät. Koulutus sisältää tutkimustietoa lasten mielenterveyden ongelmien ennaltaehkäisystä ja varhaisista interventioista. Koulutuksessa esitellään Voimaperheet-toimintamalli, -hoito-ohjelma ja siihen liittyvät tutkimustulokset sekä alueellinen Voimaperheet käyttöönottosuunnitelma. Koulutuksen järjestää Voimaperheet implementointitutkimusryhmä. Koulutuksen tavoitteena on, että alueella ymmärretään Voimaperheet-toimintamallin merkitys osana ennaltaehkäisevää näyttöön perustuvaa varhaisen vaiheen mielenterveystyötä, joka sopii osaksi neuvolan palveluvalikoimaa. Koulutuspäivään pyydetään mukaan median edustajia, jotka tukevat alueellista implementointityötä.

Jatkuva yhteistyö sisältää kuukausittain toteutetut alueelliset käyttäjäystävälliset raportit, jotka implementointitutkimusryhmä toimittaa sähköisesti esimiehille. Raportti sisältää seulontamäärät kuukausi- ja vuositasolla, sisäänottokriteerit täyttäneet, hoito-ohjelmassa olevat perheet ja keskeyttäneet perheet sekä jonossa olevat ja jäljellä olevat hoito-ohjelmapaikat. Seulonta-, sisäänottokriteerejä ja keskeyttämislukuja verrataan valtakunnalliselle tasolle. Jos esimerkiksi seulontalomakkeiden palautusprosentit pienenevät toistuvasti, otetaan alueen esimieheen yhteyttä ja tarjotaan terveydenhoitajille paikallista boosterkoulutusta joko etänä tai paikallisesti. Koko alueen ylläpitokoulutuspäiviä järjestetään vähintään joka toinen vuosi, ja niissä esitellään alueelliset Voimaperheet implementointitulokset ja Voimaperheiden tutkimustuloksia sekä uusien Voimaperheet hoito-ohjelmien kehittämistyötä. Myös erilaisen materiaalin tarjoaminen alueille on osa implementointityötä. Voima- perheet implementointitutkimusryhmä toimittaa noin kaksi kertaa vuodessa Voimapostia, joka jaetaan sähköisesti ja kirjallisesti alueille.

Säännöllinen ohjausryhmätyöskentely toteutetaan alueiden tarpeiden mukaisesti. Yhteenvetona voi todeta, että kuntayhteistyö vaatii jokaisen tason (lastenneuvolan terveydenhoitaja, lähiesimies, palvelupäällikkö ja perhepalveluiden johtaja ja johtoryhmä) yhteistyötä ja sitouttamista sekä aloitus- että ylläpitovaiheessa.

Menetelmäuskollisuuden varmistaminen. Vaikuttavuusnäytön säilyttäminen implementointivaiheessa on ensiarvoisen tärkeä tehtävä, missä digitaalisuudella ja keskittämisellä on paljon etuja. Digitaalisesti toteutettu interventio mahdollistaa puheluiden kuuntelemisen jälkikäteen ja siten laadun varmistamisen. Tiimiesimies ja kokeneemmat, tehtävään perehdytetyt perhevalmentajat kuuntelevat noin 10 prosenttia kaikista puheluista varmistaen hoitoohjelman laadun ja menetelmäuskollisuuden toteutumisen. Systemaattisella itsearvioinnilla perhevalmentaja arvioi jokaisen valmennuspuhelun jälkeen onnistumisensa. Perhevalmentajat osallistuvat kaksi kertaa kuukaudessa ryhmätyönohjaukseen, jonka tavoitteena on menetelmäuskollisuuden varmistaminen ja toisaalta haasteellisten tilanteiden läpikäyminen, mikä mahdollistaa ryhmässä oppimisen.

\section{NÄYTTÖÖN PERUSTUVIA PSYKOSOSIAALISIA MENETEL- MIÄ VÄLITTÄVÄT ORGANISAATIOT VALTAKUNNALLISESTA NÄKÖKULMASTA}

Yleisesti psykososiaalisten menetelmien arviointitietoa tarvitaan, jotta palvelujärjestelmässä tapahtuva päätöksenteko perustuu parhaaseen mahdolliseen ymmärrykseen siitä, mikä on vaikuttavaa toimintaa. Suomessa Itlan Kasvun tuki -tieteellisen toimituksen tehtävänä on tuottaa luotettavaa arviointitietoa lapsille, nuorille ja heidän perheilleen suunnatuista psykososiaalisten menetelmien vaikuttavuudesta. (https://kasvuntuki.fi/arviointikasikirja/).

Pitkällä aikavälillä eri menetelmien vaikuttavuus mitataan kuitenkin lopulta siinä, miten hyvin vaikuttavat menetelmät juurtuvat osaksi palvelujärjestelmän toimivia käytäntöjä ja miten helposti ne ovat palveluiden käyttäjien saatavilla. 
Myös menetelmäuskollisuus tulee varmistaa eli vaikuttavuuden tulee säilyä, kun siirrytään tutkimuksesta implementointivaiheeseen. Tiedetään, että kehnoimmillaan kliinisten tulosten siirtyminen terveydenhuollon käytäntöihin on saattanut kestää vuosia (Friedman ym. 2010).

Valtakunnallisesta näkökulmasta katsottuna tilanne Suomessa lasten psykososiaalisten interventioiden kohdalla ei ole imarreltava. Vaikka esimerkiksi käytösongelmien ennaltaehkäisyyn ja hoitoon Suomesta Kasvun tuki -arvioinnin perusteella on saatavilla vaikuttavia menetelmiä, niitä ei ole maantieteellisesti tarjolla systemaattisesti peruspalveluissamme. Esimerkiksi 5-12vuotiaiden lasten ohjautuminen lastenpsykiatrian erikoissairaanhoitoon lisääntyi 22 prosenttia vuodesta 2011 vuoteen 2015. Yleisimmät päädiagnoosit lapsilla, jotka ovat ohjautuneet lastenpsykiatrian erikoissairaanhoitoon ovat olleet käytöstarkkaavaisuus häiriöt (Huikko ym. 2017).

Kasvavat luvut lastenpsykiatrian palveluissa kielivät varmasti monesta asiasta. Yksi syy lienee, että järjestelmämme ei ole kyennyt siirtämään vaikuttavia interventioita valtakunnan tasolla peruspalveluihin. John Lavisin ja Heather Bullockin edellä mainitun analyysin perusteella tämä tarkoittaisi, että välittävät organisaatiot eivät ole onnistuneet toimimaan saumattomana ketjuna aina tiedon arvioinnista paikalliseen päätöksentekoon saakka. Eräs tapa hahmottaa minkälaisia välittäviä organisaatioita toiminnan saumaton siirtyminen edellyttäisi, on jakaa nämä organisaatioiden välittävien funktioiden mukaan (Wandersman ym. 2008). Tällä tavalla erottuu välittävät organisaatiot, joiden eri tehtäviä ovat: 1) syntetisoida olemassa olevaa tietoa (synthesis and translation systems), 2) tarjota koulutusta ja tukea (support systems) sekä 3) tarjota ja valita vaikuttavia menetelmiä (delivery systems).

Näiden pohjalta voidaan pohtia miten nämä näkyvät nykyjärjestelmässä Suomessa. Perusteelliseen analyysiin pitäisi luonnollisesti lisätä myös ajallinen ulottuvuus, jonka kautta olisi mahdollista todeta onko organisaatioissa tai ympäröivässä kontekstissa tapahtunut muutosta. Tässä puheenvuorossa tällaiselle perusteelliselle analyysille ei ole tilaa. On kuitenkin mahdollista todeta että, tällaisessa jaossa:

Tiedon syntetisointi ja kääntäminen (synthesis and translation systems): Kasvun tuki -tieteellinen toimitus on vuodesta 2014 toiminut orga- nisaationa, jonka tehtävänä on ollut tiedon syntetisointi ja välittäminen näyttöön perustuvista menetelmistä. Lasten ja käytösongelmien ennaltaehkäisyyn ja varhaisen vaiheen hoitoon vahvan vaikuttavuusarvioinnin saaneet menetelmät ovat Ihmeelliset vuodet vanhemmuus- ja ryhmänhallintamenetelmä sekä Voimaperheet -toimintamalli. Nuorten käytöshäiriöiden hoitoon vahvan vaikuttavuusnäytön on saanut Multidimensionaalinen perheterapia (MDFT). Parhaiten näistä on implementoitunut palvelujärjestelmään Voimaperheet-toimintamalli, jossa erityisesti digiavusteinen toteutus tuottaa alueellisesti tasa-arvoisempia käyttäjäystävällisiä palveluita (Ristkari ym. 2019).

Koulutusta ja tukea tarjoavat tahot (support systems): käytösongelmien ennaltaehkäisyyn ja hoitoon tarkoitetuille menetelmille koulutusta ja tukea ovat vuosina 2014-2020 tarjonneet Mieli ry sekä Turun Yliopiston lastenpsykiatrian tutkimuskeskus.

Vaikuttavien menetelmiä tarjoavat ja valinnasta vastaavat tahot (delivery systems): Kunnat ja maakunnalliset alueet (Sipilän hallituksen Lapsi- ja perhepalveluiden muutosohjelman aikana) vastaavat Suomessa menetelmien valinnasta.

Yllä oleva kolmijaon perusteella on helppo todeta joitakin heikkouksia välittävien organisaatioiden ketjussa. Ensinnäkin Suomesta puuttuu virallisesti määritelty taho, joka välittää tietoa vaikuttavista menetelmistä valtakunnalliselle tasolle. Vaikka Itlan Kasvun tuki -tieteellinen toimitus tuottaa tietoa, sillä ei ole mandaattia suositella menetelmiä valtakunnalliseen levitykseen. Toiseksi, koulutusta ja tukea tarjoavat tahot toimivat ulkopuolisella rahoituksella ja niillä on hyvin eri lähtökohdat tutkimuksen, seurannan ja palvelujärjestelmään kiinnittymisen näkökulmasta katsottuna. Suomessa valtakunnallista tiedonsiirtoa ja seurantaa vauhdittaisi julkisin varoin toimivat kotipesät, joiden tehtävänä olisi tukea, tutkia ja implementoida psykososiaalisia menetelmiä epidemiologisesti perusteltujen psykososiaalisten ongelmien ennaltaehkäisyyn ja hoitoon. Tätä tavoitetta edistäisi esimerkiksi se, että valtioneuvoston asetus erikoissairaanhoidon työnjaosta ja eräiden tehtävien keskittämisestä (582/2017) otettaisiin ripeästi käyttöön sen tarkoitetulla tavalla. Asetus velvoittaa lasten, nuorten ja perheiden vaativimpien palveluiden osaamis- ja tukikeskuksien luomista osaksi viittä 
yliopistosairaalaa. Asetuksen mukaan osaamiskeskusten tehtävänä on huolehtia psykoterapeuttisten ja psykososiaalisten menetelmien arvioinnista ja niiden osaamisen ylläpidosta sekä alueellisesta yhteensovittamisesta. Kolmanneksi, kunnat voivat valita itsenäisesti menetelmänsä, mikä on ongelmallista näyttöön perustuvien menetelmiin liittyvän tiedonsiirron näkökulmasta. Vaikka peruspalveluissa olisikin tahtoa tarjota vaikuttavaa tukea ja hoitoa, voi yksittäisten kuntapäättäjien olla vaikea valita ja kohdentaa menetelmiä ja resursseja oikein, mikä puolestaan vaikuttaa siihen, että perheet eivät saa yhdenvertaisesti tehokkainta ja oikea-aikaista tukea ja hoitoa.

\section{LÄHTEET}

Bullock, H \& Lavis, J. Understanding the support needed for policy implementation: a comparative analyses of the placement of intermediaries across three mental health systems. Health Research and Policy Systems 2019; 17:82.

https://doi.org/10.1186/s12961-019-0479-1

Etheredge, L M. Rapid Learning: A Breakthrough Agenda. Health Affairs 2014; Vol. 33, no. 7. https://doi.org/10.1377/hlthaff.2014.0043

Friedman, C P, Wong, A K and Blumenthal, D. Achieving a Nationwide Learning Health System: Sci Transl Med. 2010; Nov 10;2(57):57cm29. doi: 10.1126/scitranslmed.3001456

Huikko E, Kovanen L, Torniainen-Holm M, Vuori M, Lämsä R, Tuulio-Henriksson M \& Päivi Santalahti P.:

Selvitys 5-12-vuotiaiden lasten mielenterveyshäiriöiden hoito- ja kuntoutuspalvelujärjestelmästä Suomessa. THL Raportti 8/2017.

Knapp M, Mc Daid D, Parsonage M. (toim.). Mental health promotion and mental illness prevention: The economic case. London: Department of Health, 2011.

Ristkari T, Kurki M, Suominen A, Gilbert S, Sinokki A, Kinnunen M, Huttunen J, McGrath P, Sourander A. Web-Based Parent Training Intervention With Telephone Coaching for Disruptive Behavior in 4-YearOld Children in Real-World Practice: Implementation Study. J Med Internet Res 2019; 21(4):e11446. https://doi.org/10.2196/11446

Sosiaali- ja terveysministeriö. 2020. Tulevaisuuden sosiaali- ja terveyskeskus 2020-2022. Ohjelma ja hankeopas. Sosiaali- ja terveysministeriön julkaisuja 2020:3.

https://julkaisut.valtioneuvosto.fi/

handle/10024/162004

Sourander A, McGrath P J, Ristkari T, Cunningham C, Huttunen J, Lingley-Pottie P, Hinkka-Yli-Salomäki S, Kinnunen M, Vuorio J, Sinokki A, Fossum S, Unruh

\section{LOPUKSI}

Olemme kuvanneet Voimaperheet-toimintamallin kautta onnistunutta implementointia osaksi palvelujärjestelmää ja siihen vaikuttavia tekijöitä. Lisäksi olemme halunneet tuoda esiin implementointiketjussa ne kohdat, jotka vaikuttavat näyttöön perustuvien menetelmien käyttöönottoon ja juurtumiseen valtakunnallisesti. Tulevaisuuden Sote -ohjelman yhtenä keskeisenä tavoitteena on toiminnan painotuksen siirtäminen raskaista palveluista ehkäisevään ja ennakoivaan työhön. Resurssien siirtäminen korjaavista palveluista ennaltaehkäiseviin ja varhaisen vaiheen hoitoon edellyttää, että valtakunnallisessa päätöksenteossa kiinnitetään huomiota eri tahojen työnjakoon ja siihen että valintoja ohjaa vahva vaikuttavuusnäyttö.
A. Internet-assisted parent training intervention for disruptive behavior in 4-year old children. A randomized clinical rial. JAMA Psychiatry 2016; 73, $378-87$

https://doi.org/10.1001/jamapsychiatry.2015.3411

Sourander A, McGrath P, Ristkari T, Cunningham C, Huttunen J, Hinkka-Yli-Salomäki S, Kurki M, Lingley-Pottie P. Two-Year Follow-Up of Internet and Telephone Assisted Parent Training for Disruptive Behavior at Age 4. J Am Acad Child Adolesc Psychiatry 2018; 57, 658-668. https://doi.org/10.1016/j.jaac.2018.07.001

Valtioneuvoston asetus (582/2017) erikoissairaanhoidon työnjaosta ja eräiden tehtävien keskittämisestä. https://www.finlex.fi/fi/laki/smur/2017/20170582

Vorma, H, Rotko, T, Larivaara, M, Kosloff, A. Kansallinen mielenterveysstrategia ja itsemurhien ehkäisyohjelma vuosille 2020-2030.

https://julkaisut.valtioneuvosto.fi/

handle/10024/162053

Wandersman, A, Duffy, J, Flaspohler, P, Noonan, R, Lubell, K, Stillman, L, Blachman, M, Dunville, R and Saul, J. Bridging the gap between prevention research and practice: the interactive systems framework for dissemination and implementation. Am. J Community Psychol 2008; 41: 171-181. https://doi.org/10.1007/s10464-008-9174-z

\section{Petra Kouvonen}

VTT, kehitysjohtaja

Itsenäisyyden jublavuoden lastensäätiö sr., Itla

Marjo Kurki

$T t T$, tieteellinen päätoimittaja ${ }^{1}$, erikoistutkija ${ }^{2}$

Itsenäisyyden jublavuoden lastensäätiö sr., Itla ${ }^{1}$; Turun yliopisto ${ }^{2}$

Lastenpsykiatrian tutkimuskeskus ${ }^{2}$ 